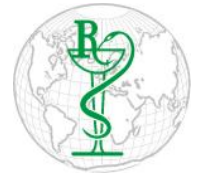

INDO GLOBAL JOURNAL OF

PHARMACEUTICAL SCIENCES

ISSN 2249- 1023

\title{
Discovery of Naturally Occurring Flavonoids as Human Cytochrome P450 (CYP3A4) Inhibitors with the Aid of Computational Chemistry
}

\author{
Sharuk L. Khan ${ }^{1 *}$, Gajanan M. Sonwane ${ }^{1}$, Falak A. Siddiqui ${ }^{1}$, Shirish P. Jain ${ }^{1}$, Mayura A. Kale ${ }^{2}$, \\ Vijay S. Borkar ${ }^{1}$ \\ ${ }^{1}$ Rajarshi Shahu College of Pharmacy, Buldana, Maharshtra, India 443001. \\ ${ }^{2}$ Government College of Pharmacy, Aurangabad, Maharashtra, India 431005
}

Address for Correspondence: Sharuk L.Khan, sharique.4u4@gmail.com

\begin{tabular}{l} 
Received: \\
13.07.2019 \\
Accepted: \\
11.04.2020 \\
Published: \\
20.12.2020 \\
Keywords \\
Human \\
Cytochrome \\
P450 (CYP3A4); \\
Flavonoids; \\
Doxorubicin; \\
Molecular \\
docking; PyRx \\
Virtual Screening \\
Tool. \\
\hline
\end{tabular}

ABSTRACT: Purpose: The human cytochrome P450 3A4 (CYP3A4) is the biggest individual from the CYP3A subfamily and records for $30-60 \%$ of the total for CYP450 adult liver. Hereditary varieties in CYP3A4 are a noteworthy hotspot for inter-patient changeability in plasma concentration, adverse effects and pharmacological response to medications. This research was done to discover naturally occurring novel CYP3A4 inhibitors from flavonoids. Methods: The molecular docking method was used to optimize the inhibiting activity of flavonoids against CYP3A4. PyRx Virtual Screening Tool 0.8 and BIOVIA Discovery Studio 2019 was used for simulation. Results: Flavonoids like Pongamoside A, Pongamoside B, and Pongamoside D have more binding affinity $(\mathrm{kcal} / \mathrm{mol})$ i.e. $-11.6,-10.9,-10.8$ respectively than Doxorubicin which have -10.7 against CYP3A4. Although, Daidzein, Genistein, and Luteolin form more hydrogen bonds than doxorubicin. Conclusion: The rational synthesis of natural analogues in reference to synthetic drugs, could generate drugs with improved therapeutic effect for chemoprevention. CYP3A4 plays a major role in the metabolism of various drugs; by the help of flavonoids, we can control the selective drug metabolism by inhibiting CYP3A4. Despite this, these molecules are not marketed for cancer treatment because of high polarity. If we could overcome this problem, these molecules can acts as effective anticancer agents in the future. Still, if we want to use these compounds clinically, there is a need to generate more scientific evidence and quality data by using in vivo and in vitro models. () 2020 iGlobal Research and Publishing Foundation. All rights reserved.

Cite this article as: Khan, S.L.; Sonwane, G.M.; Siddiqui, F.A.; Jain, S.P.; Kale, M.A.; Borkar, V.S. Discovery of naturally occurring flavonoids as human cytochrome P450 (CYP3A4) inhibitors with the aid of computational chemistry. Indo Global J. Pharm. Sci., 2020; 10(4): 58-69. DOI: http://doi.org/10.35652/IGJPS.2020.10409.

\section{INTRODUCTION}

Flavonoids are a well-known category of polyphenolic compounds. These are the regular dietary materials of the human, as many of the plants contains flavonoids. There are plenty of plants that exerts good pharmacological properties including anticancer activity just because of the presence of flavonoids. Flavonoids are the essential plant shades that act as chemical messengers, physiological controllers, and cell cycle inhibitors [1]. Flavonoids stand out amongst the most tried and broadly distributed substances of plant sources. They are found in natural products, vegetables, leguminous plants and even a few sorts of greenery. The skeleton of flavonoids comprises of 1-benzopyran. It is a C6-C3-C6 framework, in which sweet-smelling rings are associated, shaping a focal pyran or pyron cycle. Contingent upon the position to which ring is associated with the chromane, flavonoids are grouped into isoflavonoids and neoflavonoids [2].

Amongst the different other natural substances, flavonoids hold much consideration because of their noteworthy range of pharmacological activities, such as cell reinforcement, antimutagenic, antibacterial, antiangiogenic, anti- 


\section{Indo Global Journal of Pharmaceutical Sciences, 2020; 10(4): 58-69}

inflammatory, antiallergic, modulators of enzymatic activities and anti-cancer activity [3]. Apigenin, luteolin, quercetin and kaempferol, the hydroxylated flavonoids are the main constituents of various dietary products and beverages and have been the focus of extensive research over the last years. Apigenin exerts anticancer effects through the modulation of various pathways namely, apoptosis, Reactive oxygen species (ROS) and DNA damage and repair[4].

Malignant growth is one of the terrible illnesses caused by unusual cell growth and can attack different tissues. They shape a subset of neoplasms. It speaks of the greatest social insurance issues for humankind and requests a proactive system for cure [5]. It is accounted for the rate of malignancy that has been expanding in developing nations and has turned into the fourth driving reason for death around the world. Chemoprevention by phytoconstituents has advanced as a powerful procedure to control the prevalence of malignant growth. The journey of anticancer agents from plant sources began in the 1950s with the discovery of the vinca alkaloids, vincristine, vinblastine, combretastatin, and colchicine. These Phytochemicals act explicitly on tumor cells without influencing non-cancerous cells. Carcinogenesis is a mindboggling marvel that includes many signaling cascades. Phytochemicals are viewed as reasonable candidates for anticancer medication advancement due to their pleiotropic activities on target. The examination is in advancement for creating potential competitors (those can square or back off the development of disease cells without any side effects) from these phytochemicals. Numerous phytochemicals and their determined analogs have been distinguished as potential candidates for anticancer treatment. Plants serve as a source of novel compound elements and give a promising line to investigate on malignant growth. The plant and plant metabolites are the reforming sources as these are simple, more secure, easy, quick, and less dangerous as contrasted to traditional treatment methods. There is a positive relationship set up by the epidemiological examinations between expanded utilization of common items with diminished danger of disease. The mechanism responsible for chemoprevention remains essentially unidentified, however, it is likely identified with the closeness of phytochemicals related to plants. Consequently, the search for powerful and more secure natural anticancer agents have attracted the researchers throughout the world. [6,7].

The human cytochrome P450 3A4 (CYP3A4) is the biggest individual from the CYP3A subfamily and records for 30 $60 \%$ of the total for CYP450 adult liver. The CYP3A4 gene is limited on chromosome 7q21 and up to now, 41 CYP3A4 alleles have been recognized. The human CYP3A locus contains the three CYP3A gene (CYP3A4, CYP3A5, and CYP3A7), three pseudogenes, and a novel CYP3A gene named CYP3A43. Hereditary varieties in CYP3A4 are a noteworthy hotspot for inter-patient changeability in plasma concentration, adverse effects and pharmacological response to medications, for example, paclitaxel, fentanyl, tamoxifen, tacrolimus, and statins. Moreover, existing investigations have announced the role of CYP3A4 inadequate alleles in the disease susceptibility to prostate malignant growth, estrogen receptor-negative breast cancer, and type-2 diabetes [8,9].

Protein-ligand docking is a fundamental part of computeraided drug design, and it distinguishes the coupling pattern of proteins and ligands by computer simulation. Molecular docking results decide a general binding mode of a ligand. Varieties of compounds from plant sources have been accounted to have significant anticancer properties; in any case, their modes of activity have not been characterized. Molecular docking studies were performed on some flavonoids by using Autodock vina 1.1.2 in PyRx 0.8. [10]. The docking was performed utilizing receptor proteins required with cell cycle, cell development, and DNA replication, i.e., cyclin-subordinate protein kinase 2 (CDK-2), CDK-6, DNA topoisomerases I and II, B-cell lymphoma 2 (Bcl-2), vascular endothelial development factor receptor 2 (VEGFR-2), and the telomere: G-quadruplexes. By molecular docking, the bound confirmations and the coupling attachment among flavonoid and CYP3A4 as the target could be anticipated [11]. Doxorubicin, sold under the brand names adriamycin, used to treat breast malignant growth, bladder cancer, lymphoma, and intense lymphocytic leukemia was utilized for docking studies whose binding interactions were compared with the flavonoids [12].

Docking of the small molecule into the binding site of a receptor and guessing the binding interaction of the complex is a noteworthy part of the structure-based drug design process. By molecular docking, the bound conformations and the binding affinity between Flavonoids and human cytochrome P450 3A4 as the target could be predicted [13]. Table 1 represents the names and structures of doxorubicin and the flavonoids used for molecular docking. The structures of all the compounds were generated by using ChemDraw Ultra 8.0 with the help of IUPAC name took from the official website of U.S. National Library of Medicine PubChem (https://pubchem.ncbi.nlm.nih.gov/). 


\section{Indo Global Journal of Pharmaceutical Sciences, 2020; 10(4): 58-69}

Table 1. Name and Structures of compounds used for molecular docking

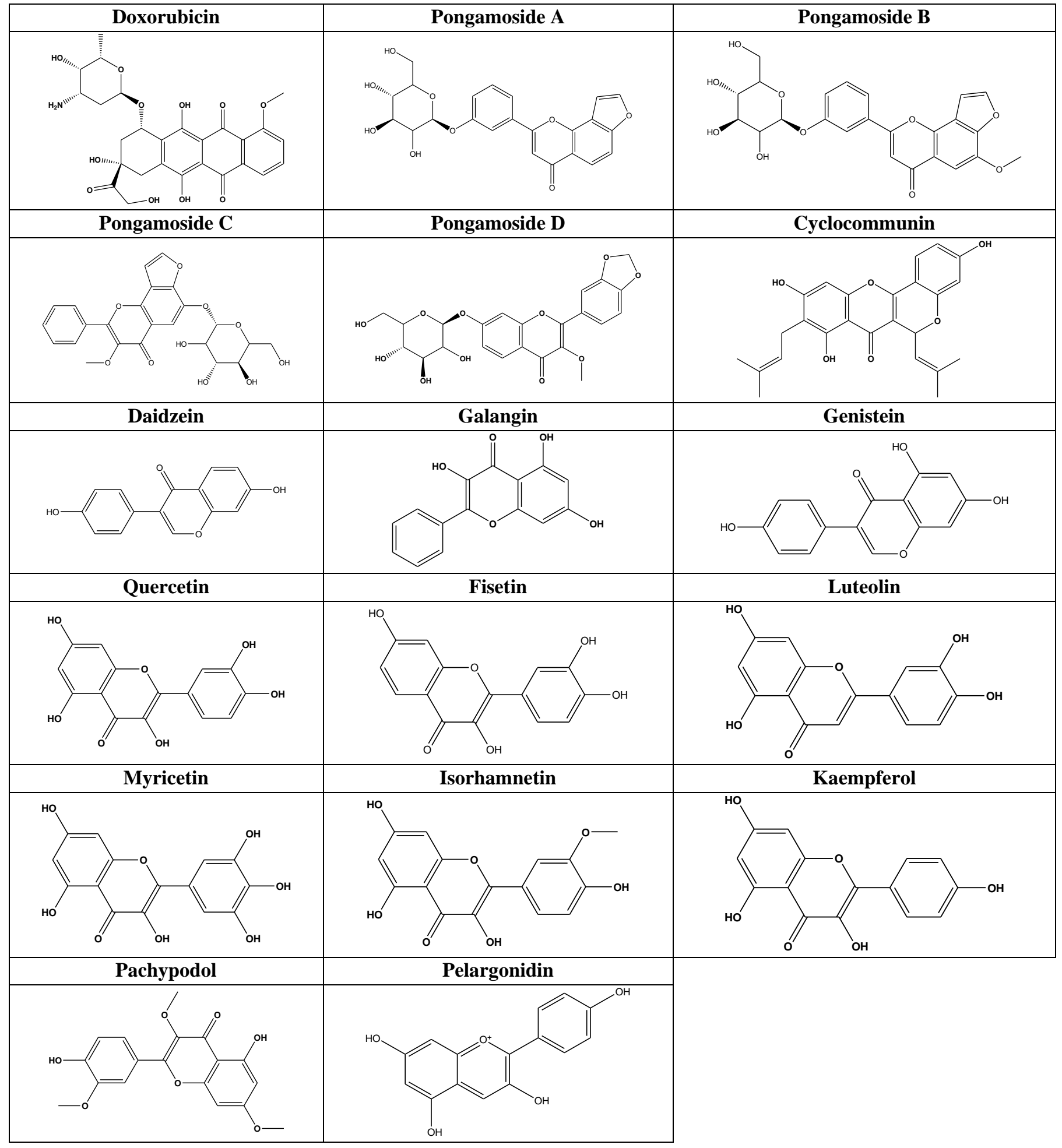

\section{MATERIALS AND METHODS}

\section{System used for Molecular docking}

Molecular docking was performed on Lenovo ThinkPad with 64-bit operating system, Processor: Intel(R) Core(TM) i54300M CPU @2.60 GHz 2.59 GHz, RAM: 4GB by using PyRx-Virtual Screening Tool.

\section{Ligand Preparation}

The Structures of all the compounds (SDF File) were downloaded from the official website of the U.S. National Library of Medicine PubChem (https://pubchem.ncbi.nlm.nih.gov/). Structures then imported into PyRx 0.8 using open bable tool and energy minimization 


\section{Indo Global Journal of Pharmaceutical Sciences, 2020; 10(4): 58-69}

(optimization) was performed by considering fundamental parameters based on the element, its hybridization, and connectivity i.e. by Universal Force Field (UFF)[16]. These ligands were then converted to AutoDock Ligand format (PDBQT).

\section{Macromolecule Preparation}

Autodock vina 1.1.2 in PyRx 0.8 was used to perform the docking studies of all the compounds against the crystal structure of human cytochrome P450 3A4 (CYP3A4). The crystal structure of CYP3A4 was obtained from the RCSB Protein Data Bank (PDB) with PDB ID-4K9T (http://www.rcsb.org/structure/4K9T) with Homo sapiens organism and Escherichia coli expression system. The CYP3A4 crystal structure was optimized, purified and prepared for docking with the help of Discovery Studio Visualizer 2019 by removing unwanted water molecules, bound ligands from protein structure and saved again in PDB file format to the same folder[17].

\section{Molecular Docking Procedure}

The purified CYP3A4 crystal structure file was loaded to docking software PyRx 0.8 using a load molecule option from the File toolbar. Chain-A was used to perform the docking, as it contains the active site which confirmed by checking interactions of native ligand present in the crystal structure (http://www.rcsb.org/3d-

view/4K9T?preset=ligandInteraction\&sele=1RD). $\quad$ The CYP3A4 crystal structure was then converted to Autodock macromolecule (pdbqt format) by using the right-click option. Binding affinity studies were performed by using Vina Wizard Tool in PyRx 0.8. All the ligand molecules (PDBQT Files), and target (CYP3A4) were selected for docking study. For molecular docking simulation, the three-dimensional grid box $($ size_x $=18.5286782874 \mathrm{Ao} ;$ size_y $=26.047226475 \mathrm{Ao}$; size_z $=-9.59195798998$ Ao) was designed using Autodock tool 1.5.6 with exhaustiveness value of 8. After selecting molecules, the active amino acid residues were selected to define the cavity with the help of Toggle Selection Spheres option given in PyRx[18]. To occupy all the active binding sites and essential residues, the grid box was aligned properly. All the ligands and CYP3A4 then subjected for docking to get the finding affinities.

\section{Identification of Cavity and Active Amino Acid Residues}

The active amino acid residues in the protein were identified and noted using BIOVIA Discovery Studio Visualizer (version-19.1.0.18287)[17]. The selection of the amino acids in the active site was used to analyze the grid box and to define the cavity. All the docking poses, ligand and protein interactions were studies by importing output files into Discovery Studio which enables us to identify the types of interactions. Discovery Studio is an offline life sciences software that offers tools to study drug-receptor interaction, docking poses visualization and macromolecule preparations. The chosen cavity was the binding site of the native ligand in PDB 4K9T.

\section{RESULTS AND DISCUSSION}

All the flavonoids and doxorubicin successfully docked on CYP3A4. Binding energy is released when a drug molecule associates with a target, leading to a lowering of the overall energy of the complex [14]. Molecular formula, Lipinski's rule of five, binding affinity $(\mathrm{kcal} / \mathrm{mol})$, and active amino acid residues are presented in Table 1. Lipinski's rule of five plays an important role in molecule screening and validation. Here, Pongamosides i.e. Pongamoside A, Pongamoside B, and Pongamoside $\mathrm{D}$ have shown better binding affinity than doxorubicin.

Table 2 represents 3D- \& 2D-images of docking poses along with no. of hydrogen bonds involved in the interaction. The 2D-docking pose also shows the chemical structure of the ligands which enables us to predict groups and/or atoms involved in the bond formation with CYP3A4.

Table 2. Properties, Lipinski's rule of five, binding affinity and active amino acid residues.

\begin{tabular}{|c|c|c|c|c|c|}
\hline Name of & Molecular & \multicolumn{2}{|l|}{ Lipinski's rule of five } & Binding & Active amino acid residues \\
\hline \multirow{4}{*}{ Doxorubicin } & \multirow{4}{*}{$\mathrm{C}_{27} \mathrm{H}_{29} \mathrm{NO}_{11}$} & Molecular weight (<500 DA) & 543.5 & \multirow{4}{*}{-10.7} & \multirow{4}{*}{$\begin{array}{l}\text { Ala370, Ile120, } \\
\text { Phe213, Vhe241, } \\
\text { Phe108, Phe220, Ile50, Tyr53, } \\
\text { Leu221, Phe57, Thr224, } \\
\text { Asp76, Glu374 } \\
\text { (Forms unfavourable bond with } \\
\text { Arg372) }\end{array}$} \\
\hline & & $\mathrm{X} \log \mathrm{P}(<5)$ & 1.3 & & \\
\hline & & H-Bond donor (5) & 6 & & \\
\hline & & H-bond acceptor $(<10)$ & 12 & & \\
\hline Pongamoside A & $\mathrm{C}_{23} \mathrm{H}_{20} \mathrm{O}_{9}$ & Molecular weight (<500 DA) & 440.4 & -11.6 & $\begin{array}{lll}\text { Leu373, } & \text { Ala370, } & \text { Arg372, }\end{array}$ \\
\hline
\end{tabular}


Indo Global Journal of Pharmaceutical Sciences, 2020; 10(4): 58-69

\begin{tabular}{|c|c|c|c|c|c|}
\hline & & $\mathrm{X} \log \mathrm{P}(<5)$ & 1.4 & & \multirow{3}{*}{$\begin{array}{l}\text { Met371, Gly481, Asp76, } \\
\text { Leu482, Ile50, Leu221, Pro218, } \\
\text { Leu216, Tyr53, Phe57, Phe220, } \\
\text { Phe108, Arg105, Glu374 }\end{array}$} \\
\hline & & H-Bond donor (5) & 4 & & \\
\hline & & H-bond acceptor $(<10)$ & 9 & & \\
\hline \multirow[t]{4}{*}{$\underline{\text { Pongamoside B }}$} & \multirow[t]{4}{*}{$\mathrm{C}_{24} \mathrm{H}_{22} \mathrm{O}_{10}$} & Molecular weight $(<500 \mathrm{DA})$ & 470.4 & \multirow[t]{4}{*}{-10.9} & \multirow{4}{*}{$\begin{array}{l}\text { Arg372, Ala370, Met371, } \\
\text { Leu216, Gly480, His54, Tyr53, } \\
\text { Leu221, Thr224, Phe57, } \\
\text { Arg106, Glu374, Arg105 } \\
\text { (Forms unfavourable bond with } \\
\text { Gly481) }\end{array}$} \\
\hline & & $\mathrm{X} \log \mathrm{P}(<5)$ & 1.4 & & \\
\hline & & H-Bond donor (5) & 4 & & \\
\hline & & H-bond acceptor $(<10)$ & 10 & & \\
\hline \multirow[t]{4}{*}{ Pongamoside D } & \multirow[t]{4}{*}{$\mathrm{C}_{23} \mathrm{H}_{22} \mathrm{O}_{11}$} & Molecular weight $(<500 \mathrm{DA})$ & 474.4 & \multirow[t]{4}{*}{-10.8} & \multirow{4}{*}{$\begin{array}{l}\text { Phe57, Leu216, Tyr53, Gly480, } \\
\text { Gly56, Leu479, His54, Leu221, } \\
\text { Ile50, Asp76, Thr224, Phe220, } \\
\text { Phe108 }\end{array}$} \\
\hline & & $\mathrm{X} \log \mathrm{P}(<5)$ & 1 & & \\
\hline & & H-Bond donor (5) & 4 & & \\
\hline & & H-bond acceptor $(<10)$ & 11 & & \\
\hline \multirow[t]{4}{*}{ Pongamoside $\mathrm{C}$} & \multirow[t]{4}{*}{$\mathrm{C}_{24} \mathrm{H}_{22} \mathrm{O}_{10}$} & Molecular weight $(<500 \mathrm{DA})$ & 470.4 & \multirow[t]{4}{*}{-10.6} & \multirow{4}{*}{$\begin{array}{lrr}\text { Leu221, } & \text { Pro218, } & \text { Leu216, } \\
\text { Asp217, } & \text { Phe57, } & \text { Phe108, } \\
\text { Ile369, } & \text { Gly481, } & \text { Met371, } \\
\text { Arg372, } & \text { Glu374, } & \text { Arg106, } \\
\text { Phe215, Thr224, Ile50, Tyr53, } \\
\text { Phe220 }\end{array}$} \\
\hline & & $\mathrm{X} \log \mathrm{P}(<5)$ & 1.6 & & \\
\hline & & H-Bond donor (5) & 2 & & \\
\hline & & H-bond acceptor $(<10)$ & 10 & & \\
\hline \multirow{4}{*}{$\frac{\text { Cyclocommuni }}{\underline{\mathrm{n}}}$} & \multirow[t]{4}{*}{$\mathrm{C}_{25} \mathrm{H}_{24} \mathrm{O}_{6}$} & Molecular weight $(<500 \mathrm{DA})$ & 420.4 & \multirow[t]{4}{*}{-10.1} & \multirow{4}{*}{$\begin{array}{lll}\text { Phe215, } & \text { Val240, } & \text { Phe108, } \\
\text { Thr224, } & \text { Glu374, } & \text { Arg372, } \\
\text { Phe220, } & \text { Phe213, } & \text { Phe241, } \\
\text { Phe304, Ile301 } & \end{array}$} \\
\hline & & $\mathrm{X} \log \mathrm{P}(<5)$ & 4.1 & & \\
\hline & & H-Bond donor (5) & 3 & & \\
\hline & & H-bond acceptor $(<10)$ & 3 & & \\
\hline \multirow[t]{4}{*}{ Daidzein } & \multirow[t]{4}{*}{$\mathrm{C}_{15} \mathrm{H}_{10} \mathrm{O}_{4}$} & Molecular weight $(<500 \mathrm{DA})$ & 254.2 & \multirow[t]{4}{*}{-9.3} & \multirow{4}{*}{$\begin{array}{l}\text { Leu221, Ile50, Asp76, Arg106, } \\
\text { Glu374, Arg372, Ala370, } \\
\text { Leu373, Phe108, Phe57, Tyr53, } \\
\text { Phe220, Thr224 }\end{array}$} \\
\hline & & $\mathrm{X} \log \mathrm{P}(<5)$ & 2.5 & & \\
\hline & & H-Bond donor (5) & 2 & & \\
\hline & & H-bond acceptor $(<10)$ & 4 & & \\
\hline \multirow[t]{4}{*}{ Galangin } & \multirow[t]{4}{*}{$\mathrm{C}_{15} \mathrm{H}_{10} \mathrm{O}_{5}$} & Molecular weight $(<500 \mathrm{DA})$ & 270.2 & \multirow[t]{4}{*}{-9.3} & Arg106, Tyr53, $\quad$ Phe220, \\
\hline & & $\mathrm{X} \log \mathrm{P}(<5)$ & 2.3 & & \\
\hline & & H-Bond donor (5) & 3 & & \\
\hline & & H-bond acceptor $(<10)$ & 5 & & \\
\hline Genistein & $\mathrm{C}_{15} \mathrm{H}_{10} \mathrm{O}_{5}$ & Molecular weight $(<500 \mathrm{DA})$ & 270.2 & -9.1 & Glu374, \\
\hline & & $\mathrm{X} \log \mathrm{P}(<5)$ & 2.7 & & Phe220, \\
\hline & & H-Bond donor (5) & 3 & & Tyr53, Asp76, \\
\hline & & H-bond acceptor $(<10)$ & 5 & & Arg106, Leu373 \\
\hline Quercetin & $\mathrm{C}_{15} \mathrm{H}_{10} \mathrm{O}_{7}$ & Molecular weight (<500 DA) & 302.2 & -8.7 & Thr224, Phe108, Tyr53, Ile50, \\
\hline & & $\mathrm{X} \log \mathrm{P}(<5)$ & 1.5 & & Leu51, Leu221, Leu216, \\
\hline & & H-Bond donor (5) & 5 & & Phe215, Gly481, Gly480, \\
\hline & & H-bond acceptor $(<10)$ & 7 & & $\begin{array}{l}\text { Phe57, Phe } 220 \\
\text { (Forms unfavourable bond with } \\
\text { His54) }\end{array}$ \\
\hline Fisetin & $\mathrm{C}_{15} \mathrm{H}_{10} \mathrm{O}_{6}$ & Molecular weight $(<500 \mathrm{DA})$ & 286.2 & -8.7 & Leu221, $\quad$ Thr224, \\
\hline & & $\mathrm{X} \log \mathrm{P}(<5)$ & 2 & & Phe220, Phe57, Phe215, \\
\hline & & H-Bond donor (5) & 4 & & Leu479, Leu216, Gly480 \\
\hline & & H-bond acceptor $(<10)$ & 6 & & \\
\hline Luteolin & $\mathrm{C}_{15} \mathrm{H}_{10} \mathrm{O}_{6}$ & Molecular weight $(<500 \mathrm{DA})$ & 286.2 & -8.6 & Phe215, Leu221, $\quad$ Phe57, \\
\hline & & $\mathrm{X} \log \mathrm{P}(<5)$ & 1.4 & & Leu479, Gly56, His54, Ile50, \\
\hline & & H-Bond donor (5) & 4 & & Phe108, Thr225, Phe220 \\
\hline & & H-bond acceptor $(<10)$ & 6 & & \\
\hline
\end{tabular}


Indo Global Journal of Pharmaceutical Sciences, 2020; 10(4): 58-69

\begin{tabular}{|c|c|c|c|c|c|}
\hline \multirow[t]{4}{*}{ Myricetin } & \multirow[t]{4}{*}{$\mathrm{C}_{15} \mathrm{H}_{10} \mathrm{O}_{8}$} & Molecular weight $(<500 \mathrm{DA})$ & 318.2 & \multirow[t]{4}{*}{-8.6} & \multirow{4}{*}{$\begin{array}{lcr}\text { Leu221, } & \text { Phe57, } & \text { Thr224, } \\
\text { Phe215, Gly480, } & \text { Leu216, } \\
\text { Leu479, Ile50, Leu51, } & \text { His54 }\end{array}$} \\
\hline & & $\mathrm{X} \log \mathrm{P}(<5)$ & 1.2 & & \\
\hline & & H-Bond donor (5) & 6 & & \\
\hline & & H-bond acceptor $(<10)$ & 8 & & \\
\hline \multirow[t]{4}{*}{$\underline{\text { Isorhamnetin }}$} & \multirow[t]{4}{*}{$\mathrm{C}_{16} \mathrm{H}_{12} \mathrm{O}_{7}$} & Molecular weight (<500 DA) & 316.2 & \multirow[t]{4}{*}{-8.4} & \multirow{4}{*}{$\begin{array}{l}\text { Leu221, Pro218, } \quad \text { Phe57, } \\
\text { Thr224, Phe220, Phe215, } \\
\text { Leu216, Gly480, Leu479, } \\
\text { Tyr53, Ile50, Leu51, His54 } \\
\text { (Forms unfavourable bond with } \\
\text { Gly481) }\end{array}$} \\
\hline & & $\mathrm{X} \log \mathrm{P}(<5)$ & 1.9 & & \\
\hline & & H-Bond donor (5) & 4 & & \\
\hline & & H-bond acceptor $(<10)$ & 7 & & \\
\hline \multirow[t]{4}{*}{$\underline{\text { Kaempferol }}$} & \multirow[t]{4}{*}{$\mathrm{C}_{15} \mathrm{H}_{10} \mathrm{O}_{6}$} & Molecular weight $(<500 \mathrm{DA})$ & 286.2 & \multirow[t]{4}{*}{-8.4} & \multirow{4}{*}{$\begin{array}{l}\text { Phe108, Phe215, } \quad \text { Phe57, } \\
\text { Gly481, Gly480, Leu216, } \\
\text { Tyr53, Phe220, Thr224 }\end{array}$} \\
\hline & & $\mathrm{X} \log \mathrm{P}(<5)$ & 9.8 & & \\
\hline & & H-Bond donor (5) & 1 & & \\
\hline & & H-bond acceptor $(<10)$ & 1 & & \\
\hline \multirow[t]{4}{*}{ Pachypodol } & \multirow[t]{4}{*}{$\mathrm{C}_{18} \mathrm{H}_{16} \mathrm{O}_{7}$} & Molecular weight $(<500 \mathrm{DA})$ & 344.3 & \multirow[t]{4}{*}{-8.3} & \multirow{4}{*}{$\begin{array}{lcr}\text { Leu221, } & \text { Pro218, } & \text { Leu479, } \\
\text { Gly480, } & \text { Phe215, } & \text { Leu216, } \\
\text { Phe220, } & \text { Thr224, } & \text { Phe108, } \\
\text { Phe57, Tyr53, His54, Ile50, } & \\
\text { Leu51 } & & \end{array}$} \\
\hline & & $\mathrm{X} \log \mathrm{P}(<5)$ & 3.1 & & \\
\hline & & H-Bond donor (5) & 2 & & \\
\hline & & H-bond acceptor $(<10)$ & 7 & & \\
\hline \multirow[t]{4}{*}{$\underline{\text { Pelargonidin }}$} & \multirow[t]{4}{*}{$\mathrm{C}_{15} \mathrm{H}_{11} \mathrm{O}_{5}^{+}$} & Molecular weight $(<500 \mathrm{DA})$ & 271.2 & \multirow[t]{4}{*}{-8.2} & \multirow{4}{*}{$\begin{array}{lcc}\text { Tyr53, } & \text { Phe215, } & \text { Gly481, } \\
\text { Phe220, } & \text { Phe108, } & \text { Leu221, } \\
\text { Phe57, Thr224, Ile50 } & \end{array}$} \\
\hline & & $\mathrm{X} \log \mathrm{P}(<5)$ & 2.1 & & \\
\hline & & H-Bond donor (5) & 4 & & \\
\hline & & H-bond acceptor $(<10)$ & 1 & & \\
\hline
\end{tabular}

Table 3. 3D- \& 2D-images of docking poses along with no. of hydrogen bonds involved.

\begin{tabular}{|l|l|l|l|}
\hline $\begin{array}{l}\text { Name } \\
\text { Compound }\end{array}$ of & 3D-docking pose & 2D-docking pose & $\begin{array}{l}\text { No. } \\
\text { hydrogen } \\
\text { bonds } \\
\text { involved }\end{array}$ \\
\hline Doxorubicin & & & 02 \\
\hline
\end{tabular}


Indo Global Journal of Pharmaceutical Sciences, 2020; 10(4): 58-69

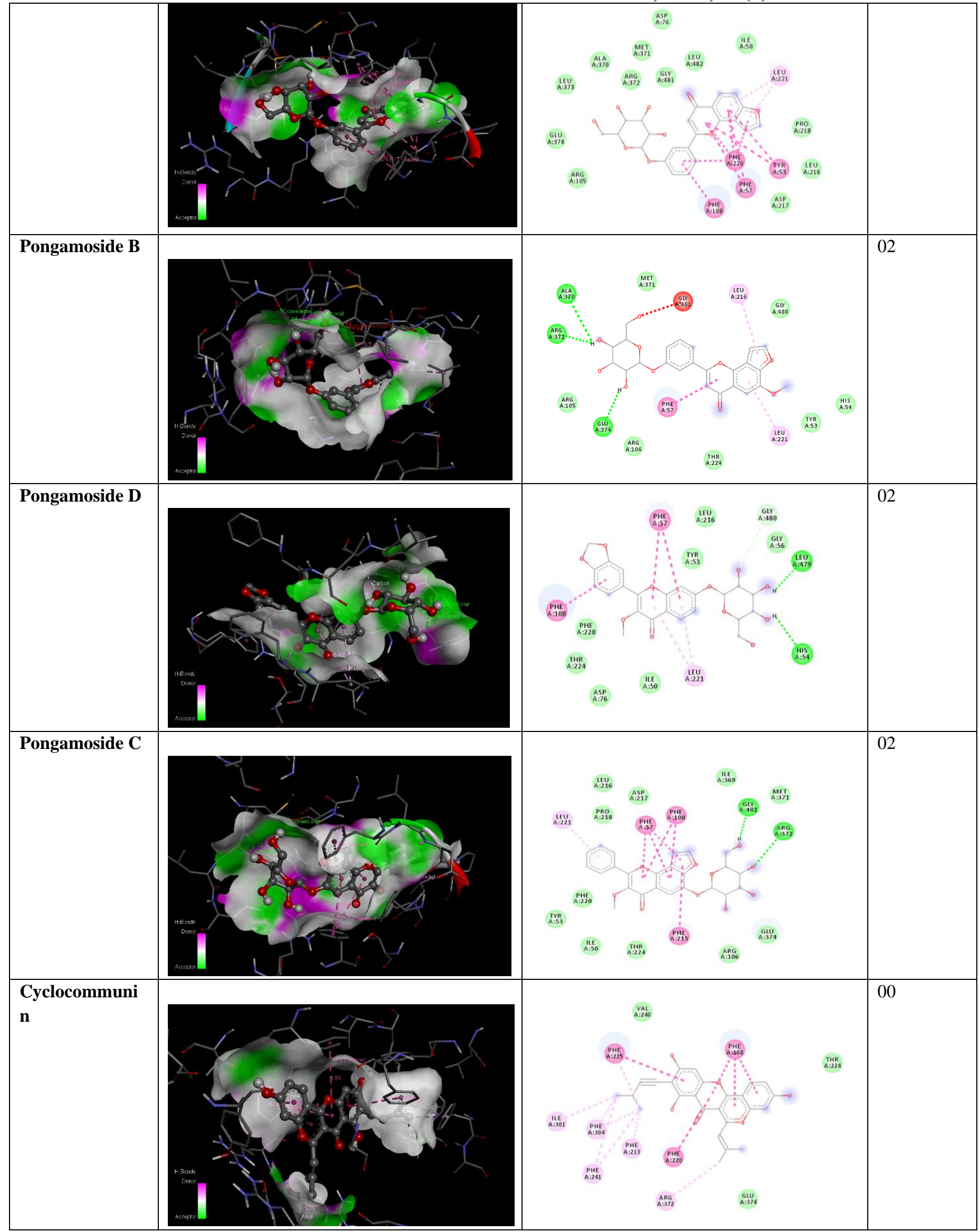


Indo Global Journal of Pharmaceutical Sciences, 2020; 10(4): 58-69

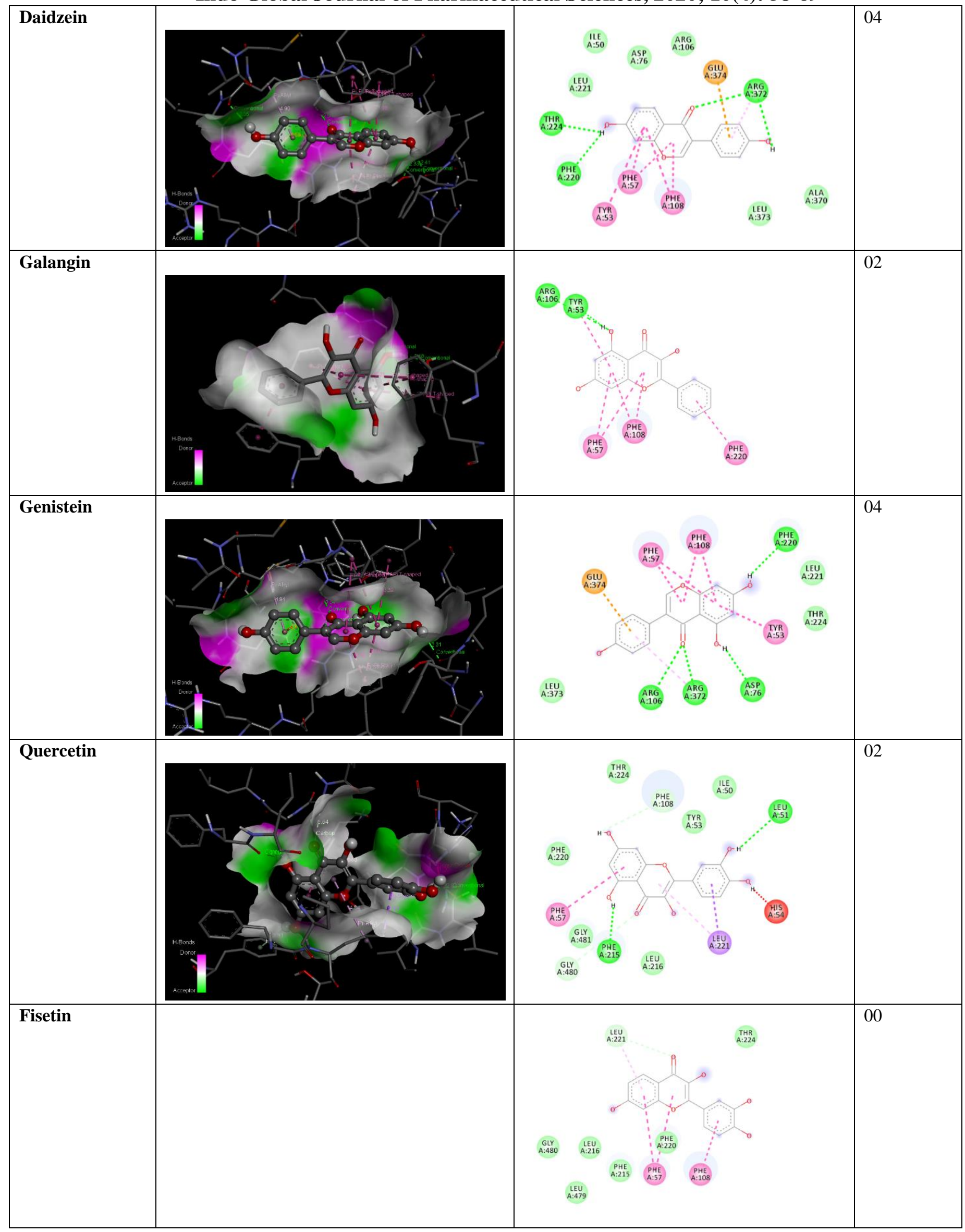


Indo Global Journal of Pharmaceutical Sciences, 2020; 10(4): 58-69

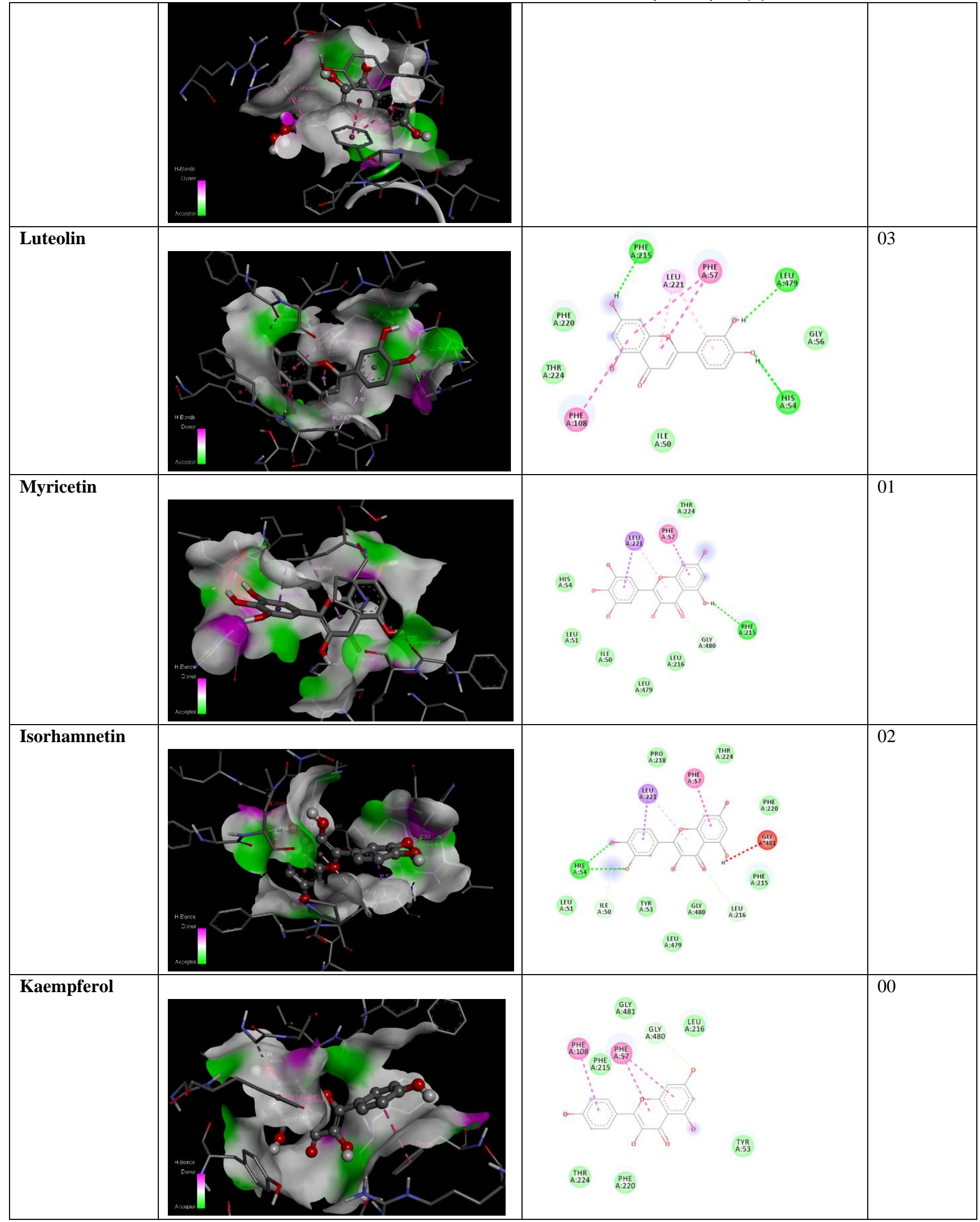


Indo Global Journal of Pharmaceutical Sciences, 2020; 10(4): 58-69

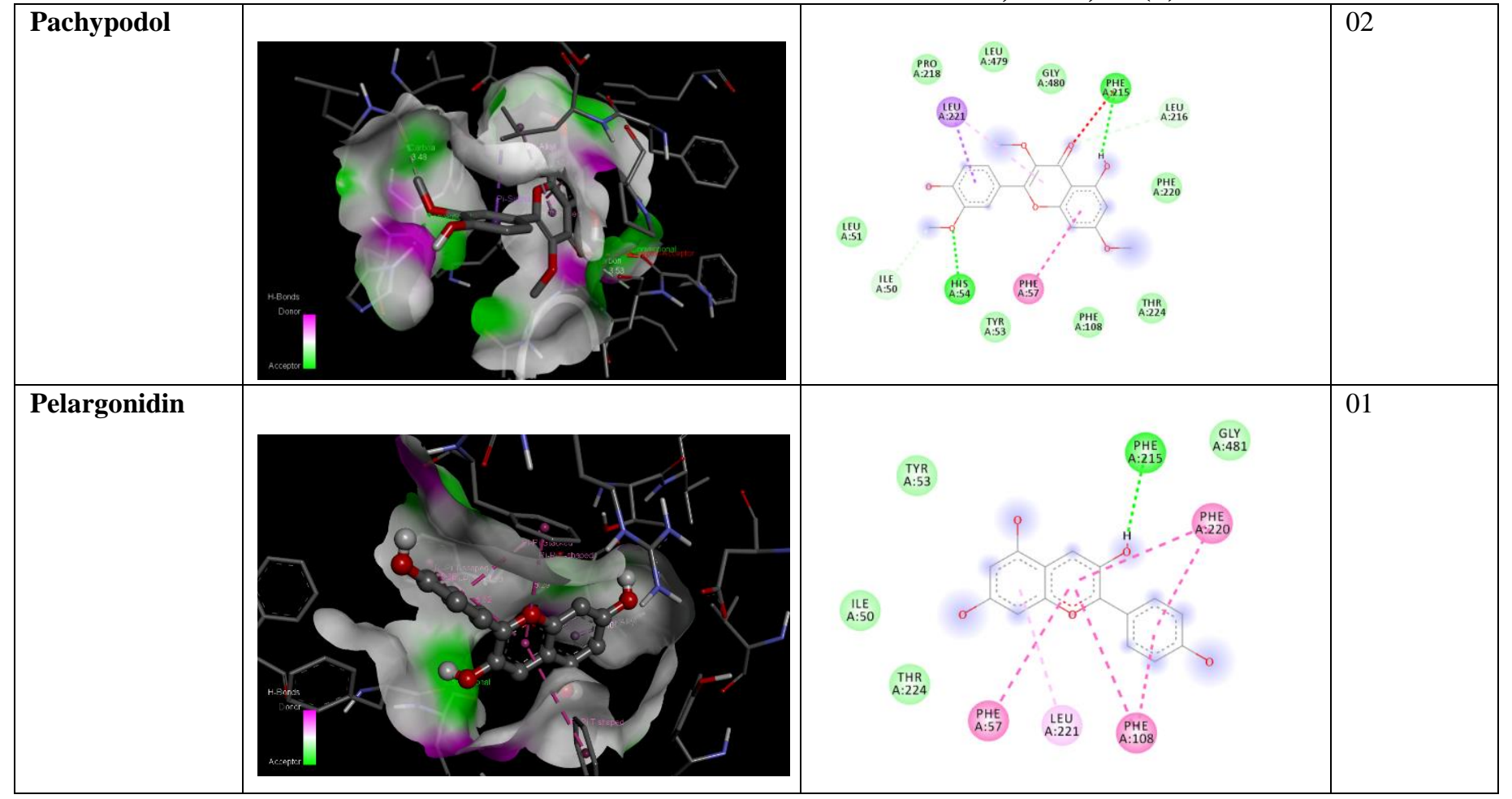

Figure 1 represents the comparative binding affinities (kcal/mol) of doxorubicin and flavonoids. Many of the flavonoids have shown better binding affinity than doxorubicin.

Figure 1. Comparative binding affinities of the compounds (Graphical presentation)

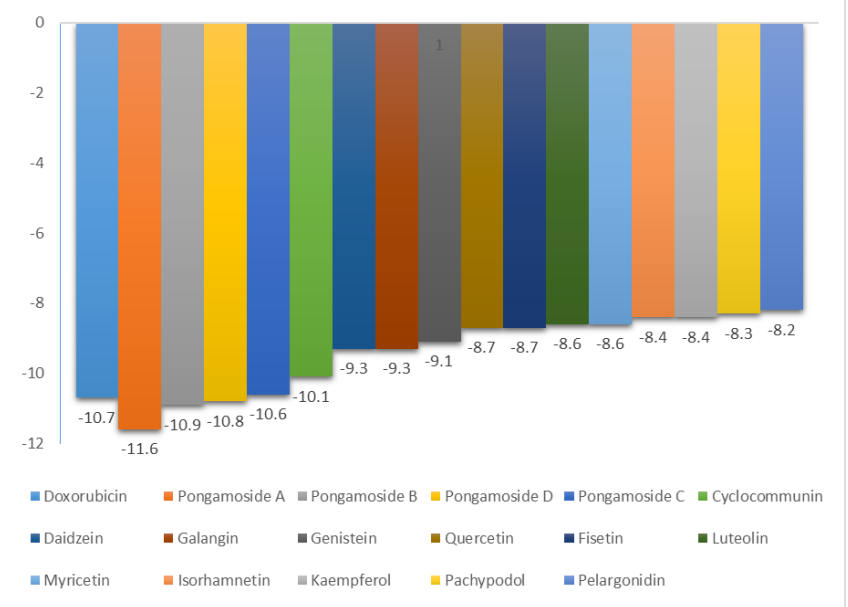

As we have represented docking data along with 2D- \& 3Ddocking poses including no. hydrogen bonds involved in the interactions in Table 2. The formation of a hydrogen bond with the target molecule always results in inhibition of the receptor. Sadhna Sinha et al reported the Molecular docking of flavones at the colchicines binding pocket which revealed that the compounds bind at $a-b$ interfacial site of tubulin, correlating binding interactions with probable inhibition mechanism. The study reveals important observations to generate improved flavonoids that leads to cell apoptosis [15]. In case of Pongamoside $\mathrm{A}$, it forms zero hydrogen bonds but still its binding affinity i.e. $-11.6 \mathrm{kcal} / \mathrm{mol}$ is best because Pongamoside A forms van der Waals force attraction, Pi-Pi Stacked bonds, Pi-Pi T-shaped bonds, Amide-Pi stacked bonds and $\mathrm{Pi}$ alkyl bonds with more amino acid residues than doxorubicin i.e. $-10.7 \mathrm{kcal} / \mathrm{mol}$ which forms two hydrogen bonds with CYP3A4. Pongamoside B and Pongamoside D have binding affinities ( $\mathrm{kcal} / \mathrm{mol})-10.9$ and -10.8 with the formation of 2-2 hydrogen bonds each with CYP3A4. This can be sufficient scientific evidence showing more potency of these flavonoids in terms of inhibition of CYP3A4 than the approved drug, doxorubicin. Although, Pongamoside C, Galangin, Quercetin, Isorhamnetin, Pachypodol forms 2-2 hydrogen bonds each with binding affinities -10.6, -9.3, -8.7, 8.4 and $-8.3 \mathrm{kcal} / \mathrm{mol}$ respectively. Surprisingly Daidzein and Genistein formed 4 hydrogen bonds each with CYP3A4 with a docking score of -9.3 and $-9.1 \mathrm{kcal} / \mathrm{mol}$ respectively which is much enough to inhibit the activity of CYP3A4. Luteolin has formed 3 hydrogen bonds with $-8.6 \mathrm{kcal} / \mathrm{mol}$ binding affinity. The amino acid residues in the cavity involved in the interactions are represented in Table $\mathbf{1}$.

\section{CONCLUSION}

It is well known that natural compounds have proven to have a safe biological window as compared to molecules from a synthetic source. In present work, molecular docking studies disclosed, that flavonoids Pongamoside A, Pongamoside B, 


\section{Indo Global Journal of Pharmaceutical Sciences, 2020; 10(4): 58-69}

and Pongamoside D have a better binding affinity towards CYP3A4 than doxorubicin. Although, if we talk about the formation of hydrogen bonds with target macromolecule, Daidzein, Genistein, and Luteolin form more hydrogen bonds than doxorubicin. In conclusion, the above docking study disclosed that rational synthesis of natural analogues in reference to synthetic drugs could generate drugs with improved therapeutic effects for chemoprevention. CYP3A4 plays a major role in the metabolism of various drugs; by the help of flavonoids, we can control the selective drug metabolism by inhibiting CYP3A4. Despite this, these molecules are not marketed for cancer treatment because of their high polarity. If we could overcome this problem, these molecules can acts as effective anticancer agents in the future. Still, if we want to use these compounds clinically, there is a need to generate more scientific evidence and quality data by using in vivo and in vitro models.

\section{ACKNOWLEDGEMENT}

None

\section{CONFLICTS OF INTEREST}

None.

\section{DATA AVAILABILITY}

Not declared.

\section{FUNDING SOURCE}

Not declared

\section{REFERENCES}

[1] Grigalius I, Petrikaite V. Relationship between antioxidant and anticancer activity of trihydroxyflavones. Molecules., 2017;22. https://doi.org/10.3390/molecules22122169.

[2] Ravishankar D, Rajora AK, Greco F, Osborn HMI. Flavonoids as prospective compounds for anti - cancer therapy. Int J Biochem Cell Biol., 2016:1-5. https://doi.org/10.1016/j.biocel.2013.10.004.

[3] Mehranfar F, Bordbar AK, Parastar H. A combined spectroscopic, molecular docking and molecular dynamic simulation study on the interaction of quercetin with $\beta$ casein nanoparticles. J Photochem Photobiol B Biol., 2013;127:100-7.

https://doi.org/10.1016/j.jphotobiol.2013.07.019.

[4] Iqbal J, Abbasi BA, Mahmood T, Kanwal S, Ali B, Shah $\mathrm{SA}$, et al. Plant-derived anticancer agents: A green anticancer approach. Asian Pac J Trop Biomed., 2017;7:1129-50.

https://doi.org/10.1016/j.apjtb.2017.10.016.

[5] Balachandran C, Sangeetha B, Duraipandiyan V, Raj MK, Ignacimuthu S, Al-Dhabi NA, et al. A flavonoid isolated from Streptomyces sp. (ERINLG-4) induces apoptosis in human lung cancer A549 cells through p53 and cytochrome c release caspase dependant pathway. Chem Biol Interact., 2014;224:24-35. https://doi.org/10.1016/j.cbi.2014.09.019.

[6] Iqbal J, Abbasi BA, Mahmood T, Kanwal S, Ali B, Khalil AT. Plant-derived anticancer agents: A green anticancer approach. Asian Pac J Trop Biomed., 2017:1-23. https://doi.org/10.1016/j.apjtb.2017.10.016.

[7] Kumar P. PLANT DERIVED ANTICANCER AGENTS AND THEIR STRUCTURE: A REVIEW. Int Res J Pharm., 2018;9:43-9. https://doi.org/10.7897/2230-8407.09687.

[8] Cacabelos R, Cacabelos P, Torrellas C. Personalized Medicine of Alzheimer' s Disease. Elsevier Inc.; 2014. https://doi.org/10.1016/B978-0-12-386882-4.00027-X.

[9] Gurusamy U, Shewade DG. Pharmacogenomics in India. Elsevier Inc.; 2014. https://doi.org/10.1016/B978-0-12386882-4.00046-3.

[10] Hejazi II, Khanam R, Mehdi SH, Bhat AR, Rizvi MMA, Thakur SC, et al. Antioxidative and anti-proliferative potential of Curculigo orchioides Gaertn in oxidative stress induced cytotoxicity: In vitro, ex vivo and in silico studies. Food Chem Toxicol., 2018;115:244-59. https://doi.org/10.1016/j.fct.2018.03.013.

[11] Rasouli H, Farzaei MH, Mansouri K, Mohammadzadeh S, Khodarahmi R. Plant cell cancer: May natural phenolic compounds prevent onset and development of plant cell malignancy? A literature review. Molecules., 2016;21:14 21. https://doi.org/10.3390/molecules21091104.

[12] Phosrithong N, Ungwitayatorn J. Molecular docking study on anticancer activity of plant-derived natural products. Med Chem Res., 2010;19:817-35. https://doi.org/10.1007/s00044-009-9233-5.

[13] Saeed M, Kadioglu O, Khalid H, Sugimoto Y, Efferth T. Activity of the dietary flavonoid, apigenin, against multidrug-resistant tumor cells as determined by pharmacogenomics and molecular docking. J Nutr Biochem., $\quad$ 2015;26:44-56. https://doi.org/10.1016/j.jnutbio.2014.09.008

[14] Mokale SN, Begum A, Sakle NS, Shelke VR, Bhavale SA. Design, synthesis and anticancer screening of 3- ( 3- ( substituted phenyl ) acryloyl ) -2H-chromen-2ones as selective anti-breast cancer agent. Biomed Pharmacother., 2017;89:966-72.

https://doi.org/10.1016/j.biopha.2017.02.089.

[15] Sinha S, Amin H, Nayak D, Bhatnagar M, Kacker P, Chakraborty S, et al. Assessment of microtubule depolymerization property of flavonoids isolated from Tanacetum gracile in breast cancer cells by biochemical and molecular docking approach. Chem Biol Interact., 2015;239:1-11. https://doi.org/10.1016/j.cbi.2015.06.034.

[16] Skiff, A. K. Rappe, C. J. Casewit, K. S. Colwell, W. A. Goddard III WMS. UFF, a Full Periodic Table Force Field for Molecular Mechanics and Molecular Dynamics Simulations. J Am Chem Soc., 2009;114:10024-35. https://doi.org/https://doi.org/10.1021/ja00051a040.

[17] Dassault Systèmes BIOVIA, Discovery Studio Modeling Environment, Release 2017, San Diego: Dassault Systèmes., 2016. 
Indo Global Journal of Pharmaceutical Sciences, 2020; 10(4): 58-69

[18] Dallakyan S, Olson AJ. Small-molecule library screening by docking with PyRx. Methods Mol Biol., 2015;1263:243-50. https://doi.org/10.1007/978-1-4939-2269-7_19.

Indo Global Journal of Pharmaceutical Sciences( ISSN 2249 1023; CODEN- IGJPAI; NLM ID: 101610675) indexed and abstracted in CrossRef (DOI Enabling), CNKI, UGC CARE Journal List, EMBASE (Elsevier), National Library of Medicine (NLM) Catalog (NCBI), ResearchGate, Publons (Clarivate Analytics), CAS (ACS), Index Copernicus, Google Scholar and many more. For further details, visit http://iglobaljournal.com 